\title{
Study of physicochemical properties of Indrayava (Holarrhena antidysenterica wall.) and its antibacterial effect on Enteropathogenic e-coli (EPEC) (in vitro)
}

\author{
Research Article
}

\section{Gawhare Vikesh $\mathbf{S}^{1^{*}}$}

1. Asst. Professor, MGACH \& RC, Salod (H), Wardha

\begin{abstract}
As stated in Ayurvedic texts Indrayava mainly useful in treatment of diseases like diarrhoea, dysentery etc. E-coli is most dangerous bacteria causing diarrhoea. Ayurveda has included all the microbes under the heading 'Krimi'. As per Bhavaprakasha Nighantu, Indrayava having Atisaraghna and Krimighna property. Hence Indrayava having action on bacteria (Krimi) may have action on E.coli causing diarrhoea (EPEC). So it is necessary to do the physicochemical standardization of Indrayava, to study its antibacterial activity on EPEC (In-vitro), to determine minimum inhibitory concentration of Indrayava for antibacterial activity against EPEC. Materials used are self collected sample, clinically isolated EPEC. Method used for antibacterial susceptibility is disc diffusion method. After study result came are, foreign matter is negligible, moisture content is $8.57 \%$, total ash is $4.61 \%$, acid insoluble ash is $0.60 \%$, water soluble ash is $6.67 \%$, water soluble extract is $33.32 \%$, alcohol soluble extract is $30.51 \%$ and $\mathrm{pH}$ is 5.42 . Indrayava shows the antibacterial activity against Enteropathogenic E-coli (EPEC) in methanolic extract having minimum inhibitory concentration value $2.0 \mathrm{gm} / 10 \mathrm{ml}$.
\end{abstract}

Key words - Indrayava, Atisaraghna, Krimighna, Krimi

\section{INTRODUCTION}

Ayurveda is the flawless ancient science of life, the word 'Ayur' literally means 'life' and 'Veda', the 'science' or 'knowledge'. This system of medicine is based on holistic approach and origin of it can be traced to as early as dawn of the civilization and Vedic period. Its aim is not just the cure of disease but the maintenance of a positive healthy state of body, mind and spirit in a healthy environment and in harmony with the universe. It also provides way of living for

*Corresponding Author:

Gawhare Vikesh Sudhakarrao,

Room No. G1, Yashoda P.G. Boys Hostel, Sawangi (Meghe), Wardha- 442001.

Mob. No. - +919028419216.

E-mail ID -drvikesh02@gmail.com prevention of disease. $(1,2)$

As traders are supplying raw materials, they are aware of knowledge of medicinal plants in terms of external appearances, similar looking drugs; hence they do the adulteration because of which patient's health is hampered. So the question arises about the safety and efficacy of the drug. Hence standardization is the key to overcome these problems. $(3,4,5)$

Indrayava is mainly useful in treatment of diseases like diarrhoea, dysentery etc. E-coli (EPEC) is most dangerous bacteria causing diarrhoea. Ayurveda has included all the microbes under the heading 'krimi'. As stated in Bhavaprakasha Nighantu, Haritkyadi varga shloka no. 158-159, Indrayava is most commonly used as Krimighna. Hence 
Indrayava having action on bacteria (Krimi) may have action on E-coli (EPEC) causing diarrhoea.

\section{AIMS AND OBJECTIVES}

1. To assess the physicochemical parameters of Kutaj beej (Indrayava)

2. Lab practical tests to evaluate antibacterial susceptibility of Indrayava against EPEC

3. To determine minimum inhibitory concentration of Indrayava for antibacterial activity against EPEC.

\section{MATERIALS AND METHODS}

Collection of sample: -

The plants of the Kutaj were identified morphologically with the standard literature and the seeds of the plant were collected in Vidarbha region in Maharashtra state in India. The sample was collected in the month of July. The sample was allowed to dry on cotton cloth in a room (temp. between $300 \mathrm{C}-350 \mathrm{C}$ ) in a such way that insect, flies and other contaminants should not damage it. The sample was powdered with khalva and passed through mesh of 72 no. size and packed in self sealed polythene based after labelling. $(6,7,8,9)$

\section{(A) PHARMACOGNOSTICAL STUDY $(10,11)$}

(1) Morphological Study:

Materials: The materials collected for the studies were.

Drug: Seeds of Kutaj (Holarrhena antidysenterica Wall.)

Equipments: Sense organs to determine the organoleptic characters of sample

\section{Methods:}

Organoleptic method- nature of the seeds, colours, taste, size, shape, odour, characteristics were studied.

(2) Microscopical study:

Materials: The materials collected for the studies were
Drug: Seeds of Kutaj (Holarrhena antidysenterica Wall.)

Equipments: Compound microscope, eye piece, camera lucida, glass slides, cover slips, watch glass, camel brush, mountain brush, filter paper, blades, spirit lamp, pipettes.

Chemicals: Phloroglucinol, Chloral hydrate, Conc. HCl. Glycerin, Iodine.

Methods:

1) Section Method

2) Staining Process Method

(B) PHYSICO-CHEMICAL STUDY $(11,12,13)$

Foreign matter

Moisture content

Total ash value

Acid insoluble ash value

Water soluble ash value

Water soluble extractive value

Alcohol soluble extractive value $\mathrm{pH}$ value

(C) PHYTOCHEMICAL STUDY $(14,15,16,17)$

1) Solubility of Indrayava

Materials: Funnels, beaker, filter paper, test tube, fine powder of Indrayava

Solvents: 1. Water 2. Ethanol 3.

Chloroform

\section{Methods:}

Test for reducing sugars:

Benedict's test: Mix equal volume of test solution and Benedict's reagent. Heat in boiling water bath --- solution appears green in colour.

Fehling's test: Add $1 \mathrm{ml}$ test solution and Fehling's solutions; boil in water bathyellow ppt.

\section{Test for starch:}

Iodine test: Mix $3 \mathrm{ml}$ of test solution and few drop of dilute iodine solution -- blue colour. 
Test for mucilage:

Add $1 \mathrm{ml}$ of test solution and $1 \mathrm{ml}$ of Ruthenium red solution ------red colour.

\section{Test for proteins:}

Biuret test: $1 \mathrm{ml}$ of test solution and few drops of Biuret reagent---pink colour.

Millon's test: $1 \mathrm{ml}$ of test solution and $2 \mathrm{ml}$ of Millon's reagent---- white ppt.

Xanthoprotein test: Mix $3 \mathrm{ml}$ of test solution with $1 \mathrm{ml}$ conc. Sulphuric acid---white ppt. is formed.

\section{Test for amino acids:}

$3 \mathrm{ml}$ of test solution and 3 drops $0.1 \%$ ninhydrin solution, heat in boiling water bath for 10mins. ----- Purple colour.

Test for oils:

Take the drug powder in the filter paper and press it----filter paper gets permanently stained with oils.

\section{Test for steroids:}

Salkowski test: $5 \mathrm{ml}$ of test solution and $2 \mathrm{ml}$ of chloroform and $3 \mathrm{ml}$ conc. sulphuric acid. Shake well ---brown ring.

Test for cardiac glycosides:

Killer- killiani test: $2 \mathrm{ml}$ of test solution. Add glacial acetic acid, a drop of ferric chloride and conc. sulphuric acid------a reddish brown ring.

Test for anthraquinone glycosides:

Borntrager's test: $3 \mathrm{ml}$ test solution, add dil. sulphuric acid. Boil and add filter. Cool and add benzene. Shake well. Separate the organic layer. Add ammonium hydroxide solution ---- pink colour.

Test for cyanogenetic glycosides:

Guignard test: Test solution, picric acid and sodium carbonate-----red colour.

\section{Test for saponins:}

Foam test: Shake the test solution with water vigorously. Allow it to stand persistent foam observed.

\section{Test for flavonoids:}

$1 \mathrm{ml}$ test solution and $5 \mathrm{ml}$ of sodium hydroxide------yellow colour, decolourises after addition of acid.

Test for alkaloids:

Add $2 \mathrm{ml}$ of test solution and a few drops of Dragendorff's reagent--orange brown ppt.

Add $2 \mathrm{ml}$ of test solution and a few drops of Wagner's reagent---reddish brown ppt.

Add $2 \mathrm{ml}$ of test solution and a few drops of Mayer's reagent ----- white ppt.

\section{Test for tannins:}

Ferric chloride test: $1 \mathrm{ml}$ test solution and a drop of ferric chloride solution ----blue ppt.

Lead acetate test: $1 \mathrm{ml}$ test solution and $1 \mathrm{ml}$ of lead acetate solution ------white ppt. \{Reference: Kokate C.K., 1999; Harbone, J.B., 1973$\}$

\section{(D) EXPERIMENTAL WORK} $(\mathbf{1 8 , 1 9 , 2 0 )}$

To evaluate the antibacterial activity of Indrayava (Holarrhena antidysenterica Wall.) the following various materials were use

\section{Materials:}

\section{A) Drugs:}

1. Methanolic extract 2. Water extract 3. Ethanolic extract of Indrayava

B) Micro organisms

Clinically isolated E-coli (EPEC) bacterias

C) Equipments:

1. Distillation apparatus,

2. Water bath

3. Petri dish

4. Borer

5. Loops and loop holder

6. Hot air oven

7. Auto clave

8. Incubator

9. Spirit lamp

10. Cotton 
11. Digital balance

12. Test tubes

\section{Method:}

Preparation of plant extracts: $2.5 \mathrm{gm}$ of samples were extracted with water, ethanol and methanol. The extracts obtained from the above were used for testing antimicrobial efficacy.

Cultural media: Standard Nutrient agar Petri plates were prepared for the growth of bacterial cultures.

Test culture: Escherichia coli.

Preparation of discs: Discs of $5 \mathrm{~mm}$ diameter were prepared from Whatman's filter paper no.41 (ash less) were cut out with a punch press and were soaked in water, alcohol, methanol for some time and then dried. Few of these discs were used as standard discs and the remaining discs were transferred to the above plant extracts for thorough moistening. They were maintained for $48 \mathrm{hrs}$ so that maximum amount of extract or active principle in it was impregnated on each disc. These discs were used for antimicrobial efficacy.

About $0.1 \mathrm{ml}$ of $8 \mathrm{hrs}$ old culture was placed in each nutrient agar plate with a Pasteur pipette. The plates were then gently rotated to spread the inoculums uniformly. Then the impregnated discs were placed on the media with a sterile forceps; 3-4 discs impregnated with plant extract.

The discs were then pressed gently on the surface so that they are not shifted from position subsequently and firmly affixed to the plate. This reacts to the uniform diffusion. All this operation was carried out aseptically. The plates were then incubated at $35-370 \mathrm{c}$ for $24 \mathrm{hrs}$.

The experiments were performed in triplicates and the average zones of inhibition were recorded.

(Chandrakant R.K., 2007; Mandal P., Sinha Babu, S.P., and Mandal, N.C., 2005; Kavitha, D., 2004; Khan, M.R., Kikhara, M. and Omoloso, A.D., 2001; Nair, A. and
Bhide, S.V., 1996; John, B.H., 1989; Kirti, S.L., 1985; Banerjee, Anup and Nigam, S.S., 1978, 197)

\section{(E) Determination of Minimum Inhibitory \\ (MIC) $(21,22,23)$}

Materials

Plant extract : Methanol extract of Indrayava

Organism used: Escherichia coli (EPEC)

Preparation of the sample solution:

$2.00 \mathrm{gm}$ of plant extract was taken in vials separately. Then $10 \mathrm{ml}$ methanol was added.

\section{Preparation of inoculums:}

The E. coli was grown at 37 degree Celsius in nutrient agar medium and was diluted in nutrient broth medium in such a manner that the suspension contains about $107 / \mathrm{ml}$. This suspension was used as the inoculums.

\section{Procedure:}

1. Twelve test tubes were taken, nine of which were marked 1, 2, 3, 4, 5, 6, 7, 8,9 , and the rest were assigned as TM(medium), TME(Medium + extract) and TMI(Medium + Inoculum).

2. $4 \mathrm{ml}$ of nutrient broth medium was poured to each of the 12 test tubes.

3 . These test tubes were cotton plugged and sterilized in an autoclave for 15 Ibs/ sq.inch pressure.

4. After cooling $2 \mathrm{ml}$ of the sample solution was added to the 1 st test tube and mixed well and then $2 \mathrm{ml}$ of this content was transferred to the test tube.

5. The content of the second test tube was mixed well and again $2 \mathrm{ml}$ of this mixture was transferred to the 3 rd test tube. This process of serial dilution was continued up to the 9th test tube.

6. $10 \mu 1$ of properly diluted inoculum was added to each of 9 test tubes and mixed well.

7. To the control test tube TME, $2 \mathrm{ml}$ of the sample was added, mixed well and $2 \mathrm{ml}$ of this mixed content was 
discarded to check the clarity of the medium in presence of diluted solution of the compound.

8. $10 \mu 1$ of the inoculum was added to the control test tube TMI, observe the growth of the organism in the medium.

9. The control test tube TM, containing medium only was used to confirm the sterility of the medium.

10. All the test tubes were incubated at 370 c for 18 hours.

\section{Result:}

A) ORGANOLEPTIC CHARACTERS

Shabda : Jvalankalin - Char-
Char, Bhanguratva : Abhangur

Sparsha : Kathin, Ruksha,

Khara

Rupa : Light yellowish

brown

Rasa : Tikta, Katu,

Kashaya

Gandha : $M r u d u$

B) PHARMACOGNOSTIC STUDY

1) Macroscopic characters: - Elongated, margins curved inside, one side convex and other side concave, 1 to $2 \mathrm{~cm}$ long, 0.2 to $0.3 \mathrm{~cm}$ thick.

2) Microscopic characters:

Testa: It is single layered radially arranged, compact parenchymatous cells filled with brown content. This layer is surrounded on the upper surface by papillose cells which looks like a trichome. Tegmen: Testa is followed by two layers of small rounded to irregular cells; few of them show the presence of prismatic shaped calcium oxalate crystals.

Just below these layers are the collapsed nucellar cells filled with brown content.

Endosperm: It is with outer and inner tangentially elongated epidermal cells covered with cuticle. They are 5-6 layered, rounded to polygonal, compactly arranged parenchymatous cells. These cells contain aleurone grains and abundant oil globules.

Cotyledons: Two foliaceous convolute cotyledons are present. Each cotyledon is single layered tabular epidermal cells towards the dorsal side and rectangular cells towards ventral side. They are covered with cuticle. The central cells are polygonal, compactly arranged, with oil globules and prism shaped calcium oxalate crystals. There are poorly developed vascular bundles at the groove region.

\section{Powder Study:}

Calcium oxalate crystals: abundant, prism shaped calcium oxalate crystal measuring $0.8-1 \mu \mathrm{m}$ in length and $1.2-1.5$ $\mu \mathrm{m}$ in breadth.

Parenchymatous cells of cotyledon: polygonal, with starch grains, measuring $2-6 \mu \mathrm{m}$ in diameter.

Oil globules: round in shape, measuring 1$2 \mu$ min diameter

Papillose cells: broken pieces of elongated cells measuring $1.4 \mu \mathrm{m}$ in diameter.

Cells of endosperm: the cells are polygonal, compactly arranged, parenchymatous, measuring 1.3-1.7 $\mu \mathrm{m}$ in diameter.

Cells of tegmen: irregular to polygonal fragments of parenchymatous cells measuring 0.9-1.6 $\mu \mathrm{m}$ in diameter.

C) PHYSICOCHEMICAL VALUES

a) Foreign matter : Nil

b) Moisture content $\quad: \quad 08.57 \%$

c) Total ash

$04.61 \%$

d) Acid insoluble ash : $\quad 00.60 \%$

e) Water soluble ash : $\quad 06.67 \%$

f) Water soluble extract : $33.32 \%$

g) Alcohol soluble extract : $30.51 \%$

h) $\mathrm{pH}$ value $\quad: 05.42$

D) PHYTOCHEMICAL STUDIES

Reducing sugar, amino acids, alkaloids, tannins, proteins, cardiac glycosides, Anthraquinone Glycosides, oils, flavonoids are present in water, Ethanol \& chloroform extract and saponins present only in water extract. Starch, mucilage, steroids are absent in all the three extracts.

E) ANTIBACTERIAL ACTIVITY

Table1. Showing antibacterial susceptibility against EPEC

\begin{tabular}{|l|l|l|}
\hline $\begin{array}{l}\text { Name of } \\
\text { organism }\end{array}$ & Extract & $\begin{array}{l}\text { Diameter of zone } \\
\text { of inhibition }(\mathrm{mm})\end{array}$ \\
\hline
\end{tabular}




\begin{tabular}{|l|l|l|}
\hline \multirow{3}{*}{ E coli } & Water & - \\
\cline { 2 - 3 } & Ethanol & - \\
\cline { 2 - 3 } & Methanol & 12 \\
\hline
\end{tabular}

F)_ MINIMUM

INHIBITORY

CONCENTRATION (MIC) VALUE
AGAINST EPEC

Table 2 showing MIC value against EPEC

\begin{tabular}{|l|l|l|l|l|}
\hline $\begin{array}{l}\text { No. } \\
\text { of } \\
\text { test } \\
\text { tub } \\
\text { es }\end{array}$ & $\begin{array}{l}\text { Nutri } \\
\text { ent } \\
\text { broth } \\
\text { medi } \\
\text { um } \\
\text { added } \\
(\mathrm{ml})\end{array}$ & $\begin{array}{l}\text { Diluted } \\
\text { solutio } \\
\mathrm{n} \text { of } \\
\text { plant } \\
\text { extract } \\
(\mathrm{gm} / 10 \\
\mathrm{ml})\end{array}$ & $\begin{array}{l}\text { Inocul } \\
\text { um } \\
\text { added } \\
\mu l\end{array}$ & $\begin{array}{l}\text { Observat } \\
\text { ions }\end{array}$ \\
\hline 1 & 4 & 0.1 & 10 & + \\
\hline 2 & 4 & 0.5 & 10 & + \\
\hline 3 & 4 & 1.00 & 10 & + \\
\hline 4 & 4 & 1.5 & 10 & + \\
\hline 5 & 4 & 2.00 & 10 & - \\
\hline 6 & 4 & 2.1 & 10 & - \\
\hline 7 & 4 & 2.2 & 10 & - \\
\hline 8 & 4 & 2.3 & 10 & - \\
\hline 9 & 4 & 2.5 & 10 & - \\
\hline TM & 4 & 0.1 & 10 & - \\
E & & & & \\
\hline TM & 4 & 0 & 10 & + \\
I & & & 10 & - \\
\hline TM & 4 & 0 & & \\
\hline
\end{tabular}

'+' Indicates growth '_' Indicates no growth

In E. coli the growth of the organism was observed in the test tube no. 4 , indicating that the MIC value of the plant extract was $2.00 \mathrm{gm} / 10 \mathrm{ml}$.

\section{Discussion:}

1. Holarrhena antidysenterica is a drug which is easily available. It is also being sold in market. Indrayava is being used in many diseases as per Ayurvedic classics. It is mainly useful in treatment of diseases like diarrhoea, dysentery etc. Indrayava is a sangrahi. It is most commonly used as krimighna. Ayurveda has included all the microbes under the heading krimi. Indrayava is kriminashaka as explained earlier. Hence Indrayava having action on bacteria may have action on E.coli. E-coli is most dangerous bacteria causing diarrhoea. Day by day this bacteria is resistant to most of the higher antibiotics like Ampicillin, Tetracycline, Cotrimoxazole etc. In modern drug study, the preclinical study is essential to carry out the clinical trials. Antibacterial activity is part of it. Hence it is a need of today's era to evaluate the antibacterial activity of Indrayava against E.coli.

2. Result shows that the rasa of Indrayava is Tikta, Katu, Kashaya, Veerya is Sheet and Vipaka is Katu. The drug is sparingly soluble in water, alcohol, oil and ghee (ghrit).

3. Indrayava is elongated; margins curved inside, one side convex and other side concave, 1 to $2 \mathrm{~cm}$ long, 0.2 to $0.3 \mathrm{~cm}$ thick. Microscopic characters show testa, tegmen, collapsed nucellar cells, endosperm containing aleurone grains and abundant oil globules, two foliaceous convolutes cotyledons.

4. Powder study reveals abundant, prism shaped calcium oxalate crystal, parenchymatous cells of cotyledon, oil globules, papillose cells, cells of endosperm, cells of tegmen.

5. The drug is standard as all the tests show result within the normal limit as per Ayurvedic Pharmacopoeia of India vol.III.

6. Drug show antibacterial activity against E-coli in methanolic extract only.

7. Minimum inhibitory concentration for the antibacterial activity against E-coli $(\mathrm{EPEC})$ in methanolic extract is $2 \mathrm{gm} / 10 \mathrm{ml}$.

8. So, extract of Indrayava powder is effective against Enteropathogenic Escherichia Coli (EPEC) in methanolic extract at the minimum inhibitory concentration of $2 \mathrm{gm} / 10 \mathrm{ml}$ which is already mentioned in ayurvedic text the Krimighna property and antidiarrhoeal property of Indrayava. 
9. The further research is required for providing efficacy of the drug in animals and then patients

\section{Conclusion:}

From the discussion it is concluded that the self collected sample of Indrayava is standard with respect to its pharmacognostical, physicochemical, phytochemical test. Antibacterial study with reference to E.coli shows the positive results in methanolic extract of Indrayava. It does not show zone of inhibition in water and ethanolic extracts. This is due to the active constituents which are dispersible in methanol may have antibacterial action against EPEC. The other constituents which are soluble in water and ethanol may not have antibacterial activity against EPEC. The minimum inhibitory concentration requires for antibacterial activity of Indrayava against EPEC is $2.00 \mathrm{gm} / 10 \mathrm{ml}$.

\section{References:}

1. Pandit Kashinath Pandey, Dr. Gorakhanath Chaturvedi, Charak Samhita (Vidyotani Vyakhya) Vol.II, Chaukhamba Bharati Acadami Varanasi, Reprint 2003, p568-569.

2. Anantram Sharma, Sushrut Samhita (Sushrutavimarshini Hindi Vyakhya) Vol. II, Chaukhamba Surabharati Prakashan Varanasi, Reprint 2004, p255.

3. Shree Harinarayana Sharma, Ashtang Hridaya (Moolmatra), Chaukhamba Bharati Acadami Varanasi, Reprint 2008, p107.

4. Shree Ambikadatta Shastri, Bhaishajyaratnavali, Chaukhamba Sanskrit Sansthan Varanasi, Revised ed.1993, p203.

5. Pro. Krishnachandra Chunekar, Bhavaprakasha Nighantu (Savimarsha Hindi Vyakhya), Chaukhamba Bharati Acadami Varanasi, Revised and enlarge ed.2010, 163,258.
6. Vd. Panchanan Pandit, Madanpala Nighantu, Khemaraj Shrikrishna Prakashan Mumbai, Reprint 1998, p27.

7. Acharya Priyavat Sharma, Kaiyadeva Nighantu, Chaukhamba Orientalia Varanasi, First ed.1979, p165.

8. Dr. Guruprasad Sharma, Dhanvantari Nighantu, Chaukhamba Orientalia Varanasi, First ed.1982, p72.

9. Dr.Indradev Tripathi, Raj Nighantu, Krishnadas academy Varanasi, First ed. Vikram sanvat 1939, p274.

10. CSER, The Wealth of India Raw Materials Vol.I, CSER, Reprint 1988, p327.

11. Colonel K.R.Kirtikar, Major B.D.Basu, Indian Medicinal Plants Vol.II, Lalit, Basu Allahabad, Second ed. Second reprint 1981, p1570.

12. Bapalal Vaidya, Nighantu Aadarsh Vol.I, Chaukhamba Vishvabharati Academy, Reprint 2007, p847.

13. Prof. Gyanendra Pandey, Shodhala Nighantu, Chaukhambha Krishnadas Academy Varanasi, First ed. 2009, p57.

14. IDMA, Indian Herbal Pharmacopoeia, Indian Drug Manufacturer Association Mumbai, Revised ed. Nov.2002.

15. U.C. Dutt, Materia Medica of The Hindus, Krishnadas Academy Varanasi, Third ed. 1980, 193, p308.

16. Acharya Priyavat Sharma, Dravyaguna Vidnyan Vol.II, Chaukhamba Pratisthan Varanasi, Second ed.1977, p463.

17. Acharya Priya Vrat Sharma, Dravyagunakosha, Chaukhambha Orientalia Delhi, p43

18. Prof. Ramsushil Singh, Vanaushadhi Nidarshika Ayurvedic Pharmacopoeia, Uttar Pradesh Hindi Sansthan Lukhnow, Third reprint, p111.

19. P.C.Sharma, M.B. Yelne, T.J. Dennis, Database of Medicinal Plants Vol. II, CCRAS New Delhi, First ed.2001, reprint 2002, p347. 
20. Dr.K.M. Nadkarni, Indian Materia Medica, Popular Book Depot, Mumbai, Third ed. 1976, p634.

21. Dr. Pannikar, Textbook of Microbiology, Revised ed. 2002, p270273.

22. Nanda Maheshwari, Clinical Microbiology, Jaypee Brothers, Med. Pub. New Delhi, First ed.2005, p214.

23. CCRAS, The Ayurvedic Pharmacopoeia of India Vol.III, CCRAS New Delhi, First ed. 2001, p67-68.

\section{Acknowledgements:}

With the blessing of God Dhanwantari I completed my research project in a comprehensive manner. I sincere thanks to my father Mr. Sudhakarrao and my mother Mrs Rekha for their constant support and admonition, this work cannot be completed without their help. Last but not the least the whole credit goes to my sincere efforts. 


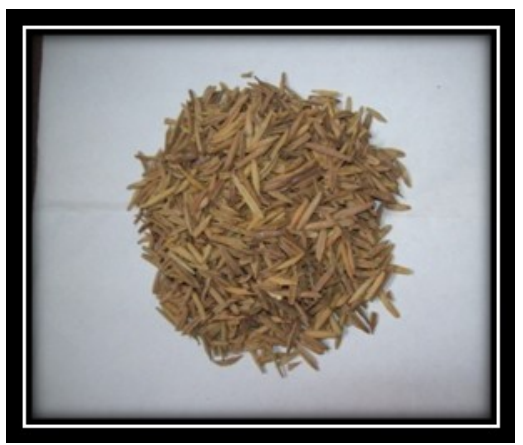

Fig. 1

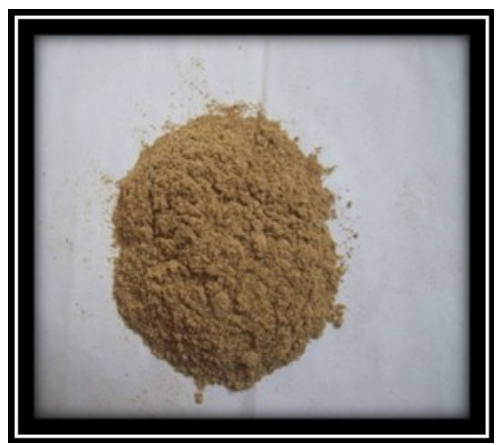

Fig.2

Fig. 1\&2 Showing Macroscopic Characters

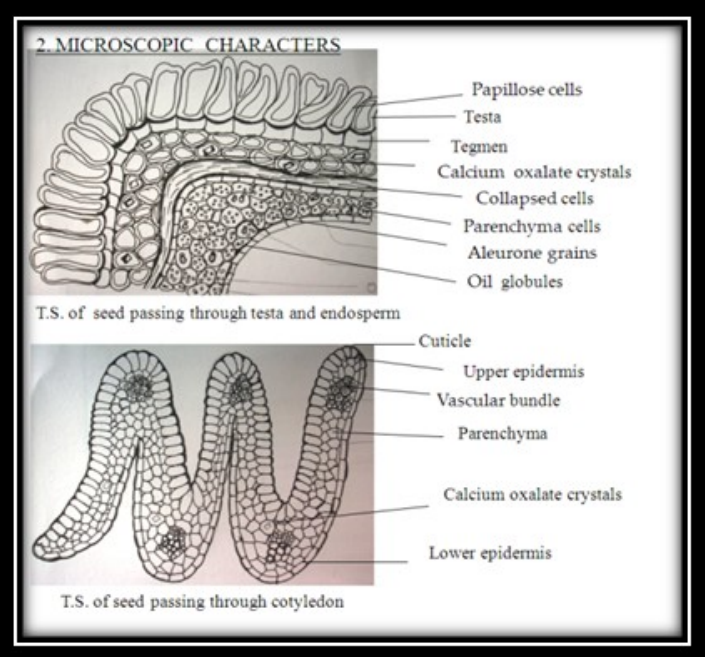

Fig. 3 Showing Microscopic Characters

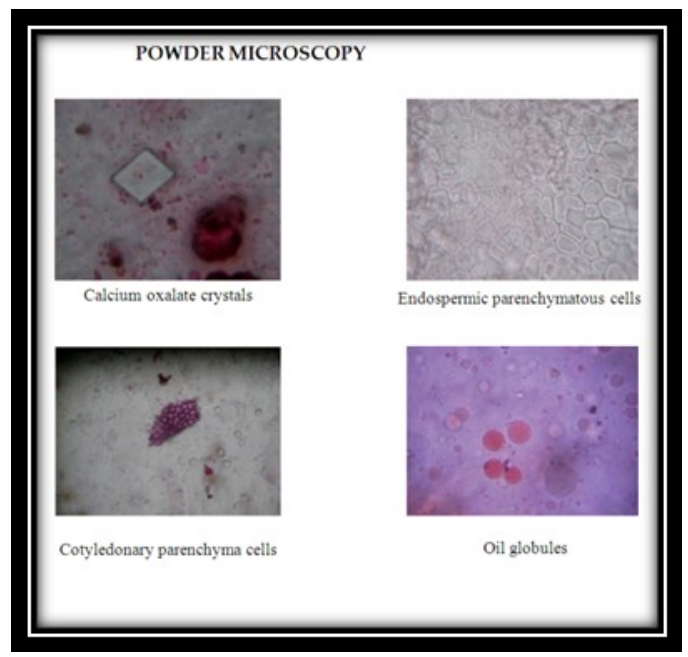

Fig. 4 Showing Powder Study

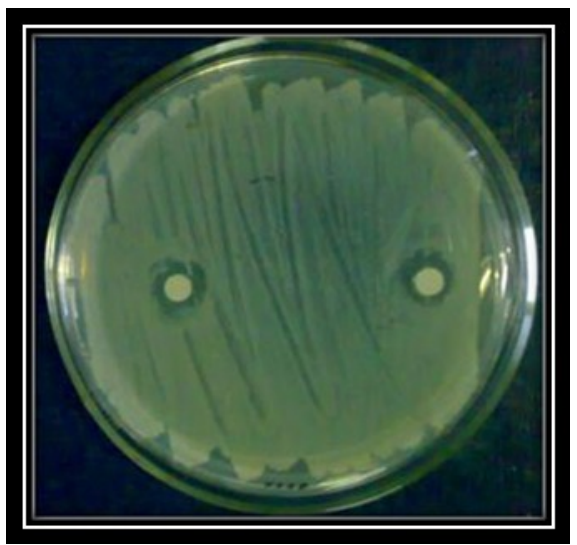

Fig 5 Zone Of Inhibition

$* * * *$ 